UDC 81'373.45

DOI: $10.17223 / 24109266 / 11 / 6$

\title{
LINGUISTIC AND CULTURAL CORRELATIONS, CONTRASTS AND DIFFERENCES BETWEEN THE RUSSIAN AND THE ENGLISH LANGUAGES, LANGUAGE CULTURE AND TRADITION
}

\begin{abstract}
A.V. Pilyukova, N.G. Zarechneva
Abstract. In this article, some linguistic findings of research into analytical and correlative techniques between the Russian and the English languages, their cultures and traditions are presented. The authors have made an attempt to discuss the various factors and conditions which provide the basis for such things and phenomena. It should be emphasized that the aim of the correlative research into various languages to present only successive definition of contrasts and differences between the Russian and the English languages. Thus, a two-way, binary system of correlation between both the languages should be taken into consideration. Based on these differences, various groups to be correlated are discussed in the present paper. All the points are illustrated by the examples taken from the sphere of biology and the other related subjects and disciplines. Studying Russian and English is its various aspects is useful in modern times particularly for Master`s degree students, those young people who take their post-graduate course and also for the learners of English on a wide scale.
\end{abstract}

Keywords: a plethora of cultures, indispensable, thematic groups, differences, distinctions, synthetic, analytical.

\section{Introduction}

Currently the problems of the analytical and correlative methods of linguistics have been given much attention to. Unlike the comparative method which is predominantly historical and pragmatic, the correlative technique is aimed at establishing different things and phenomena common to each individual language. The aim of the correlative research into various languages is to present only successive definition of contrasts and differences between the Russian and the English languages. It is interesting to note that the idea of a language correlation was introduced by the well-known linguist Ferdinand de Saussure into his article "A Course of General Linguistics" [1] in which the ideas of language systematics were discussed. Later on the scholar's views were developed in the works of his followers such as L.V. Sherba, S.I. Polivanov, A.V. Isachenko, A.A. Reformatsky, et al.

People of various nations and cultures perceive one another in a different way. They are quite different owing to a plethora of cultures, customs and traditions. When people learn the language of the other nation better, the boundaries among countries become conditional and nations come closer together. 
Figuratively speaking, the language is a song of people with the help of which any cultural community expresses it thoughts, ideas and wishes. The language performs various important functions, it also provides the basis for many national myths, fairytales, legends.

In addition, many significant state documents are written and signed by means of the language. Many scientific ideas, theories and discoveries make their appearance owing to the language as well.

The English language has become an international language thanks to its relative grammar simplicity, openness and flexibility. It should be noted that English has adopted many Russian words such as большевик, перестройка, дача, борщ, квас, дума, интеллигениия, кремль и др. All these words do not require translating into English because they are equally perceived by the Russian and English people.

In the historical retrospect English was in many instances identical to the Russian language. To be more exact, it was a highly inflexional language and had the gender characteristics and some specific features associated with that. Historically, or in the process of evolution, the English language developed and simplified which resulted in the loss of inflexions causing a lot of difficulties both in Russian and English.

To this must be added the fact that the English verbs do not change their endings depending on the person or number; nouns and adjectives do not have inflections or gender endings. The Russian language also developed during the evolutionary process but retained the inflexions and gender characteristics. The parts of speech of many English words are defined according to their place in a sentence.

It is interesting to note that just one and the same word in English may serve as the noun, the adjective and the verb as well. It is well illustrated using such words as "drink", "kiss" and "look". E.g. We chill champagne in iсе. Мы охлаждаем шампанское в ведерке со льдом. Мы чувствуем прохладу по утрам.

All things considered, English has become a means of communication for many people living in various continents. It is interesting to note that English has many advantages over the other languages such as the absence of inflexions and gender characteristics. Its advantages over the other languages usually manifest themselves in the spheres of business and science where its compactness, clearcut expression of the thought and the rules of logic make it indispensable.

It should be noted that the expression «в двух словах» sounds in English like this "in a word" (одним словом). From the above line of reasoning much is understood in the culture of the other people.

Thus, the historical roots of Russian and English are quite different. According to its structure, Russian belongs to the group of synthetic languages, whereas English is an analytical language where the structure of a sentence is of crucial importance. 
As a matter of fact, in synthetic languages, such as for instance Russian, the grammatical relations between words are expressed by means on inflexions: е.g. свойство этого вещества. In analytical languages such as English, the grammatical relations between words are expressed by means of form words and word order the property of the substance. Owing to the scarcity of synthetic forms the word order which is fixed in English, acquires significant importance: The fisherman caught a fish.

It is interesting to note that there are many words in English and Russian which have one and the same meaning. These words are the following: revolution, communism, progress, inflation and so on. And now let's examine the English word "sympathy" and the Russian word «симпатия». The pronunciation is almost identical but the meanings are quite different. The first word is translated into Russian as «сочувствие» while the second one is rendered in Russian as «симпатия». In a word, good English is a profound comprehension of the originality and unique nature of Russian.

The classification of the correlations, contrasts and differences between Russian and English according to their linguistic and cultural characteristics.

1. Russian: The language is inflective, complex grammar relations and nuances of a meaning are often expressed by only one word.

In English all these meanings are made of several words because English is an analytical language.

2. Russian: There are many impersonal, indefinite-personal, reflexive and passive constructions.

English: The constructions with the clearly expressed subject prevail. There are no reflexive verbs and the constructions of the Passive Voice do not occur very often. E.g. I am cold; the wind blew off the old fence, etc. (Мне холодно; ветер снёс старую изгородь и т.д.).

Syntax of the Russian language tends to use impersonal constructions. In this peculiarity S.G. Terminasova and the other linguists in the book "Language and Intercultural Communication" see agnosticism, irrationality, fatality of the Russian people [2]. Such a variety of impersonal constructions reflects the tendency of Russian to look at the world as a combination of events which have defied explanation. Such a stylistic peculiarity can be explained by the collectivism mentality of the Russian people. Man is not looked upon as an active doer of the action and it frees him from responsibility for everything which is going on around him [3].

Whereas impersonal syntactic models are used in Russian, personal forms and constructions take place in English.

Thus, in Russian all actions and responsibility for doing them are impersonal because the individual depends upon many other persons of a society, nature, some unknown, unidentified forces:

Мне надо - I must;

Мне нужно - I have to do; 
Мне хочется - I want;

Думается, что - I think;

Мне холодно - I am cold.

In English a person takes over or accepts duties and responsibilities for doing something.

3. Russian: The absence of the category of the article is characteristic of English.

English: In English the article is a structural part of speech used with nouns.

English: The category of the article is typical of several European languages. Some linguists think that this category confirms and underlines the role of the individual in the culture and ideology of the West.

4. Russian: It should be noted that the personal pronoun " $\{$ » is not capitalized in Russian. This pronoun is written with a small letter because it can be explained by the fact that it seems contrary to the mentality and character of the Russian people.

English: In English this pronoun is always capitalized because it demonstrates a great interest directed to an individual, his or her personality and mentality [4].

5. Russian: As far as the Russian language is concerned, the use of the nouns is prelevant in the official speech. The Genitive case of the noun is widely used in Russian.

English: The English language abounds in numerous chains of words. It is due to the absence of inflexions in English. There exist complex relations among the words in attributive constructions where the last word in a chain of words is regarded as the key word. The following attributive constructions serve as an example to illustrate these cases.

E.g.:

- soil nutrients;

- soil erosion rates;

- city water supply system;

- animal behavior student;

- crop rotation patterns;

- vitamin deficiency syndrome;

- mushroom fruit body formation.

6. Russian: The Russian language abounds in the so called negative constructions or the structures of double negation. E.g. Никто ничего не смог сделать, чтобы помочь ему.

In English affirmative sentences prevail and the negation does not occur very often.

The following sentences may serve as an example in this respect:

Не вешайте трубку! - Hold on!

Не менее важно... - It is equally important... 
По газонам не ходить! - Keep off the grass!

He nponadaŭ! - Keep in touch!

Посторонним вход воспрещён! - Authorized personnel only!

Не позволяйте детям шалить. - Keep the children out of mischief.

Не унывай. - Keep at it / Stay with it.

7. This group of the classification deals with the expression of modality both in Russian and in English.

It is well known that modality is used to show the speaker's attitude toward the action or state indicated by the infinitive. Modality shows the relation of the statement to the reality [4]. The modal verbs (in English) show that the action indicated by the infinitive is regarded as possible, impossible, probable, improbable, obligatory, necessary, advisable, doubtful or uncertain, etc.

Russian: It should be noted that simple modality prevails in Russian. A thought is expressed in a straightforward way and in a somewhat final and categorical manner.

E.g. May I read the letter?

No, don't please.

or

You must not smoke so mush.

English: There are many words and constructions in the speech of educated English and American people. Such words and constructions sound like this: seems to, apparently, I would think, presumably etc.

E.g. Presumably the bad weather has delayed the train. По-видимому (вероятно), плохая погода задержала прибытие поезда.

$\mathrm{He}$ is apparently a friendly person. Вероятно (очевидно), он производит впечатление дружелюбно настроенного человека.

They seem to know little about the research done in this scientific laboratory. По-видимому, им мало известно об исследовании, проводимом в этой научной лаборатории.

8. This group of differences between the Russian and the English languages is devoted to the word order which is of great importance in both of the languages.

Russian: Word order in Russian is flexible and each word in a sentence has its own meaning. Due to the wealth of inflexions word order in Russian is rather free as the inflections show the function of each word in a sentence.

E.g.:

Я этого ему не говорила.

Ему я этого не говорила.

Этого я ему не говорила.

Я не говорила ему этого.

Не говорила я ему этого. 
An English speaker will say it in the following way: I did not say that to him.

English: As English words have hardly any inflexions and their relation to each other in shown by their place in the sentence and not by their form, word order in English is fixed [4]. We cannot change the position of different parts of the sentence at will especially that of the subject or the object. It should be noted that something new in Russian is often communicated just at the end of a sentence. In English the situation is quite different because something new in communicated just at the beginning of a sentence.

Е.g. Выдающимся генетиком был Г. Мендель. - Gregor Mendel was an outstanding geneticist.

9. Russian: Agreement of the predicate with the subjects presents a certain problem to the Russian learners of English. In Russian such a problem practically does not exist for native speakers although there are some exceptions in this respect.

English: In the English language the predicate agrees with the subjects in person and number. But in Modern English there is often a conflict between form and meaning; in these cases the predicate does not agree with the subject [Ibid.].

Several rules of agreement of the predicate with the subject should be observed:

1) When two subjects in the singular are connected by the conjunction as well the predicate is in the singular.

E.g. Activity as well as cell structure is an essential condition of life.

Активность, а также клеточное строение являются важными условиями жизни.

2) When two homogeneous subjects in the singular are connected by the conjunctions not only... but (also), neither... nor, either... or, or, nor, the predicate is usually in the singular.

E.g. Neither I nor my brother is to blame.

Нельзя винить ни меня, ни моего брата.

3) If the subject of different number the predicate agrees with the subject that stands first.

E.g. There was much traffic at night and many trucks on the roads.

Ночью было сильное движение транспорта и много грузовиков на дорогах.

4) The expression a number is used in the plural and the number is used in the singular.

A number of (=several) post-graduates are present at the meeting.

E.g. The number of nonresident students is this group is rather small.

5) If the subject is expressed by a group of words denoting arithmetic calculations the predicate is usually in the singular. 
E.g. Two weeks in enough time for a nice vacation. - Две недели вполне достаточное время для прекрасных каникул.

6) There are several English nouns which are always used in the plural (physics, herpes, measles, news). They agree with the predicate which is in the singular.

E.g. The news was very bad. - Новости были очень плохими.

Physics is a difficult exact science. - Физика - сложная точная наука.

10. Russian: In Russian there is a great difference between the literary, official business and colloquial styles. Within the literary style a distinct difference between the functional styles (scientific, publicistic, business etc.) is found. It should be mentioned that the art of making formal speeches is unique because it abounds in various rhetorical techniques (long lists of adjectives, expressive means, parallel constructions etc.).

English: The differences between the literary and colloquial styles are quite a rare thing. Within the literary style a distinction between the functional styles practically is not felt. The style of the English oratorical speech and the art of public speaking are different from those in Russian.

\section{Conclusion}

On the basis of the analytical and correlative methods discussed earlier we can come to the conclusion that these techniques are valid and relevant. It should be noted that the analytical and correlative methods are radically different from those of comparative techniques, the latter are based on some historical evidence. As far as the analytical and correlative methods are concerned, they focus on definite and practical aims and tasks which include the theoretical basis to explain these methods in detail.

Correlation results from the systematic antithetical categories of the Russian and English languages. The idea of the systematic character of some language facts and elements is one of the prerequisites to the techniques of analysis and correlation. Consequently, a two-way, binary system of correlation of both languages is presented in the article concerned.

To master the standards and rules of a foreign language you should find a way of a conscious starting from your native tongue.

The growing interest in the study of Russian and English, their cultures as part of intangible heritage is regarded as evidence of the processes of globalization [5]. The authors of the article concerned have made an attempt to comment on the historical roots, conditions and the present-day state of things in the spheres of these two great languages. As far as Russian is concerned, it is the Slavonic language formed as the result of certain historical events and conditions. English comes from a branch of the Indo-European family of languages. Nowadays it is the most widely spoken language in the world. English owes its exceptionally large vocabulary to its ability to bor- 
row and absorb words from outside. Based on these peculiarities and differences between Russian and English, several thematic groups of such distinction suggested by the authors are discussed in this article. All the groups (there are ten of them) are illustrated by the examples taken from the sphere of biology and the other related subjects and disciplines. A conclusion is made that studying Russian and English in the spheres of linguistics and cross-cultural relations is useful in modern times particularly for Master's degree students, those young researchers taking a post graduate course at the University, and also for the learners of English on a wide scale.

\section{References}

1. De Saussure, F.: Course in General Linguistics, New York : McGraw-Hill Book Co. (1966)

2. Ter-Minasova, S.G.: Language and Inter-Cultural communication, Moscow University Publishing House, pp. 274-276 (2004)

3. Chuzhakin, A., Palazhenko, P.: Introduction to interpreting Valent Publishing House, pp. 17-21 (2002)

4. Kaushanskaya, V.L., et al.: A grammar of the English language, Moscow, pp. 316-317 (2009)

5. Smokotin, V.M., Gural, S.K.: Search for ways of realizing inter-language and inter-cultural communication in the words ranging from the projects of artificial languages to the language of world communication, Tomsk University Publishing House, pp. 1; 153-155 (2017)

Information about the authors:

Pilyukova A.V. - Senior Lecturer, Department of the English Language of Natural Science and Physics and Mathematics Faculties of National Research Tomsk State University (Tomsk, Russia). E-mail: Zarechng@gmail.com

Zarechneva N.G. - Senior Lecturer, Department of the English Language of Natural Science and Physics and Mathematics Faculties of National Research Tomsk State University (Tomsk, Russia). E-mail: Zarechng@gmail.com 